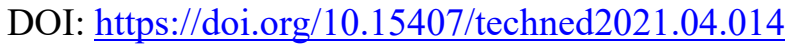

\title{
ROBUST DIRECT FIELD ORIENTED CONTROL OF INDUCTION GENERATOR
}

\author{
S. Peresada ${ }^{1^{*}}$, S. Bozhko ${ }^{2 * *}$, S. Kovbasa ${ }^{1 * * *}$, Y. Nikonenko ${ }^{1 * * * *}$ \\ ${ }^{1}$ National Technical University of Ukraine "Igor Sikorsky Kyiv Polytechnic Institute", \\ Peremohy av. 37, 03056 Kyiv, Ukraine, \\ e-mail: sergei.peresada@gmail.com \\ ${ }^{2}$ University of Nottingham, NottinghamNG7 2RD, United Kingdom
}

\begin{abstract}
A novel and robust field oriented vector control method for standalone induction generators (IG) is presented. The proposed controller exploits the concept of direct field orientation and provides asymptotic rotor flux modulus and DClink voltage regulations when a DC-load is constant or slowly varying. Flux subsystem, designed using Lyapunov's second method, has, in contrast to standard structures, closed loop properties and therefore is robust with respect to rotor resistance variations. A decomposition approach on the base of the two-time scale separation of the voltage and torque current dynamics is used for design of the voltage subsystem. The feedback linearizing voltage controller is designed using a steady state IG power balance equation. The resulting quasi-linear dynamics of the voltage control loop allows use of simple controllers tuning procedure and provides an improved dynamic performance for variable speed and flux operation. Results of a comparative experimental study with standard indirect field oriented control are presented. In contrast to existing solutions, the designed controller provides system performances stabilization when speed and flux are varying. It is experimentally shown that a robust field oriented controller ensures robust flux regulation and robust stabilization of the torque current dynamics leading to improved energy efficiency of the electromechanical conversion process. The proposed controller is suitable for energy generation systems with variable speed operation. References 18 , figures 8 .
\end{abstract}

Keywords: induction generator, direct field orientation, flux observer, DC-link voltage stabilization, variable speed, energy generation.

Introduction. Variable speed electrical energy generation is an efficient technology widely applied in diesel-, hydro- and wind-power stations, ground vehicles, aerospace and naval power systems [1] - [5]. The main advantage of variable speed generation is higher achievable energy efficiency of the primary mover and electrical generator.

The vector controlled doubly-fed induction generators (DFIG) allow production of constantfrequency electric power from a primary mover, the speed of which varies within a slip range, typically 20 $30 \%$ [2]. AC-DC-AC power electronics configuration is commonly used for permanent magnet synchronous generator (PMSG) based systems [4] known as the most advanced generation systems for modern wind power stations. Nevertheless, the cost of PMSG is significantly higher compared to an induction machine due to use of rare-earth magnetic materials, which have a very limited origin. In addition, their cost is continuously increasing. The tendency to reduce usage of expensive rare-earth magnets has driven a renewed interest for research into advanced design and control concepts for squirrel-cage machines. An alternative approach is known as vector controlled induction generation. Vector or field-oriented control (FOC) [6], advanced FOC [7] and direct torque control [8], reported in a large number of publications since 1990s, are de facto considered as the industrial standard for energy generation systems based on IG. Both classical rotor- as well as stator-field orientations [6], [7], [9] are studied as control concepts in publications.

In case of standalone applications, the induction generator controller regulates the DC-link voltage,

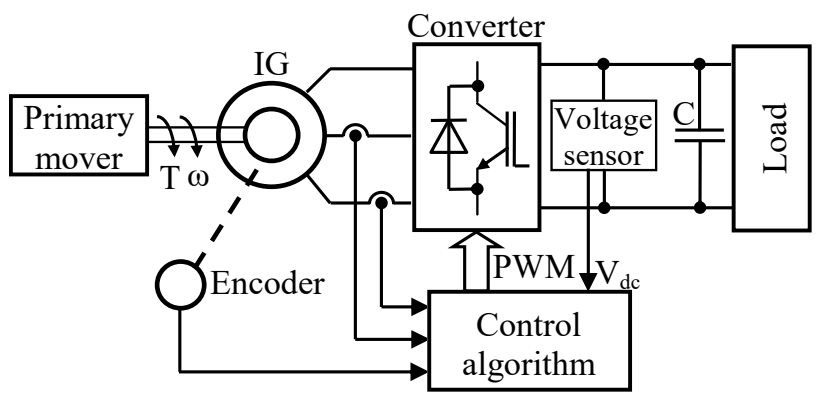

Fig. 1

(C) Peresada S., Bozhko S., Kovbasa S., Nikonenko Y., 2021

ORCID ID: *https://orcid.org/0000-0001-8948-722X; **https://orcid.org/0000-0002-0508-7198;

***https://orcid.org/0000-0002-2954-455X; ****https://orcid.org/0000-0003-2379-5566 
as shown in Fig. 1, by controlling the torque component of the stator current.

A standard IG control structure is similar to induction motor speed control system with PI speed controller replaced by a DC-bus PI voltage controller. Nevertheless, this similarity arises from the simplified consideration of the DC-link voltage dynamics, which is nonlinear since it follows the input-output power balance of the IG-converter system. A typical approach for such systems design is based on linearization of the voltage dynamics [10] - [12] and application of different control techniques for linear systems, like the frequency domain approach, worst case and Lyapunov based design, etc. Most of the contributions take into consideration the saturation effect in the IG model to enable operation with variable flux in field weakening regimes and for losses optimization.

It is well known that vector controllers with rotor flux orientation are sensitive to rotor resistance variations due to machine heating. Therefore, a field oriented flux controller does not provide asymptotic field orientation and flux modulus regulation; this leads to a degradation of the torque control performance and reduce the efficiency of electromechanical energy conversion. This problem is well studied for motor vector control systems, but has not been widely addressed for IG systems.

At present, the published studies have established both the theoretical and the practical methodologies to construct the vector-controlled IG systems to satisfy the requirements of a wide spectrum of applications. However, most of them are based on strong simplifying assumptions (neglected nonlinear dynamics, linearized models, current feed conditions etc.). In addition, stability of the existing systems has not been proven theoretically since the performance specification and the controller tuning are very complex. Robustness to the parameters variation is still an open research topic.

The aim of this work is to design and verify a novel vector control system for IG that improves the robustness with respect to the rotor resistance variations, as well as dynamic performance and efficiency of the energy conversion.

The main contribution of this paper is a novel voltage-flux controller design procedure that provides an asymptotic rotor flux regulation together with asymptotic direct field orientation and asymptotic DC-link voltage stabilization. In contrast to existing solutions, the flux subsystem is designed using Lyapunov's $2^{\text {nd }}$ method and is operated using estimated flux current error feedback. Such design guarantees:

- an exponential convergence of flux subsystem regulation errors to zero;

- decoupling from the voltage control;

- and improved robustness, hence improved dynamic performance and efficiency of the energy conversion.

Voltage-flux decoupling allows design of the voltage subsystem using a decomposition approach based on the two-time scale separation of the voltage and torque current dynamics. The theoretical findings of this paper and the effectiveness of the proposed approach are confirmed by thorough experimental validation. The paper is an expanded and further developed version of the earlier conference papers [13], [14].

The paper is organized as follows. The IG model and control problem formulation are given first. Further the flux-voltage controller design is revealed. Next, the experimental results are reported, these are followed by the Conclusions of the study.

Model of induction generator and control problem statement. For the purpose of this study, the $1 / \lambda$-saturated IG model reported in [15] has been employed. The model assumes that only the magnetizing inductance $\mathrm{L}_{\mathrm{m}}$ is saturated hence the leakage inductances are constant, and neglects the cross-saturation inductance so static and dynamic magnetizing inductances are equal.

The following definitions are used: static inductance of the magnetizing circuit is $\mathrm{L}_{\mathrm{m}}\left(\mathrm{i}_{\mathrm{m}}\right) \triangleq \psi_{\mathrm{m}}\left(\mathrm{i}_{\mathrm{m}}\right) / \mathrm{i}_{\mathrm{m}}$, where $\psi_{\mathrm{m}}\left(\mathrm{i}_{\mathrm{m}}\right)$ is magnetizing curve, and $\mathrm{i}_{\mathrm{m}}$ defines magnetizing current; stator and rotor inductances, respectively are $\mathrm{L}_{1}\left(\mathrm{i}_{\mathrm{m}}\right)=\mathrm{L}_{\mathrm{m}}\left(\mathrm{i}_{\mathrm{m}}\right)+\mathrm{L}_{1 \sigma}, \mathrm{L}_{2}\left(\mathrm{i}_{\mathrm{m}}\right)=\mathrm{L}_{\mathrm{m}}\left(\mathrm{i}_{\mathrm{m}}\right)+\mathrm{L}_{2 \sigma}$, where $\mathrm{L}_{1 \sigma}=$ const and $\mathrm{L}_{2 \sigma}=$ const are stator and rotor leakage inductances.

Under these assumptions, the two-phase model of saturated electrical part of IG in an arbitrary rotating reference frame (d-q) is given as follows:

$$
\begin{aligned}
& \dot{\mathrm{i}}_{\mathrm{d}}=-\gamma_{\mathrm{m}} \mathrm{i}_{\mathrm{d}}+\omega_{0} \mathrm{i}_{\mathrm{q}}+\alpha_{\mathrm{m}} \beta_{\mathrm{m}} \psi_{\mathrm{d}}+\omega \beta_{\mathrm{m}} \psi_{\mathrm{q}}+\mathrm{u}_{\mathrm{d}} / \sigma_{\mathrm{m}}, \\
& \dot{\mathrm{i}}_{\mathrm{q}}=-\gamma_{\mathrm{m}} \mathrm{i}_{\mathrm{q}}-\omega_{0} \mathrm{i}_{\mathrm{d}}+\alpha_{\mathrm{m}} \beta_{\mathrm{m}} \psi_{\mathrm{q}}-\omega \beta_{\mathrm{m}} \psi_{\mathrm{d}}+\mathrm{u}_{\mathrm{q}} / \sigma_{\mathrm{m}}, \\
& \dot{\psi}_{\mathrm{d}}=-\alpha_{\mathrm{m}} \psi_{\mathrm{d}}+\alpha_{\mathrm{m}} \mathrm{L}_{\mathrm{m}}\left(\mathrm{i}_{\mathrm{m}}\right) \mathrm{i}_{\mathrm{d}}+\omega_{2} \psi_{\mathrm{q}}, \\
& \dot{\psi}_{\mathrm{q}}=-\alpha_{\mathrm{m}} \psi_{\mathrm{q}}+\alpha_{\mathrm{m}} \mathrm{L}_{\mathrm{m}}\left(\dot{\mathrm{i}}_{\mathrm{m}}\right) \mathrm{i}_{\mathrm{q}}-\omega_{2} \psi_{\mathrm{d}}, \\
& \dot{\varepsilon}_{0}=\omega_{0}, \varepsilon_{0}(0)=0 \\
& \mathrm{P}_{\mathrm{s}}=-(3 / 2)\left(\mathrm{u}_{\mathrm{d}} \mathrm{i}_{\mathrm{d}}+\mathrm{u}_{\mathrm{q}} \mathrm{i}_{\mathrm{q}}\right),
\end{aligned}
$$


where $\mathrm{u}_{\mathrm{d}}, \mathrm{u}_{\mathrm{q}}$ are stator voltage components (here and throughout the paper subscripts ' $\mathrm{d}$ ' and ' $\mathrm{q}$ ' denote vector variable components in the $\mathrm{d}-\mathrm{q}$ reference frame), $i_{\mathrm{d}}, \mathrm{i}_{\mathrm{q}}$ are stator currents, $\psi_{\mathrm{d}}, \psi_{\mathrm{q}}$ define the rotor flux components, $\omega$ is the rotor speed, $\varepsilon_{0}$ is the angular position of the d-q reference frame with respect to a fixed stator reference frame $(\mathrm{a}-\mathrm{b})$ in which physical variables are defined, $\mathrm{P}_{\mathrm{s}}$ denotes active power produced by IG.

Slip frequency is defined as $\omega_{2}=\omega_{0}-\omega$. One pole pair is assumed without loss of generality. In the model (1) constants (all positive) related to IG electrical parameters are given by

$$
\begin{aligned}
& \alpha_{\mathrm{m}}=\mathrm{R}_{2} / \mathrm{L}_{2}\left(\mathrm{i}_{\mathrm{m}}\right), \beta_{\mathrm{m}}=\mathrm{L}_{\mathrm{m}}\left(\mathrm{i}_{\mathrm{m}}\right) /\left[\mathrm{L}_{2}\left(\mathrm{i}_{\mathrm{m}}\right) \sigma_{\mathrm{m}}\right], \\
& \gamma_{\mathrm{m}}=\mathrm{R}_{1} \sigma_{\mathrm{m}}^{-1}+\alpha_{\mathrm{m}} \beta_{\mathrm{m}} \mathrm{L}_{\mathrm{m}}\left(\mathrm{i}_{\mathrm{m}}\right), \sigma_{\mathrm{m}}=\mathrm{L}_{1}\left(\mathrm{i}_{\mathrm{m}}\right)-\mathrm{L}_{\mathrm{m}}^{2}\left(\mathrm{i}_{\mathrm{m}}\right) / \mathrm{L}_{2}\left(\mathrm{i}_{\mathrm{m}}\right),
\end{aligned}
$$

where $R_{1}, R_{2}$ are stator and rotor resistances respectively. The index ' $m$ ' in (2) is used to denote the parameter's dependency on magnetizing current $\mathrm{i}_{\mathrm{m}}$. From the practical assumption that there is a constant relationship between any pair of $L_{1}\left(i_{m}\right), L_{2}\left(i_{m}\right)$ and $L_{m}\left(i_{m}\right)$ it can be concluded that $\alpha_{m} L_{m}\left(i_{m}\right)=\alpha L_{m}=$ const , where $\mathrm{L}_{\mathrm{m}}=$ const is the machine magnetizing inductance at the rated flux. Magnetizing curve and $\mathrm{L}_{\mathrm{m}}\left(\mathrm{i}_{\mathrm{m}}\right)$ for induction machine used for experimental investigations are given in [14].

Transformed variables in (1) are defined according to

$$
\mathbf{x}_{\mathrm{dq}}=\mathbf{e}^{-\mathrm{J} \varepsilon_{0}} \mathbf{x}_{\mathrm{ab}}, \mathbf{x}_{\mathrm{ab}}=\mathbf{e}^{\mathrm{J} \varepsilon_{0}} \mathbf{x}_{\mathrm{dq}},
$$

where $\mathbf{e}^{-\mathbf{J} \varepsilon_{0}}=\left[\begin{array}{cc}\cos \varepsilon_{0} & \sin \varepsilon_{0} \\ -\sin \varepsilon_{0} & \cos \varepsilon_{0}\end{array}\right], \mathbf{J}=\left[\begin{array}{cc}0 & -1 \\ 1 & 0\end{array}\right], \mathbf{x}_{\mathrm{yz}}$ stands for two-dimensional voltage, flux and stator current vectors.

Produced by IG electrical power $\mathrm{P}_{\mathrm{s}}$ is transferred to DC-link by IGBT converter. Assuming an ideal converter without losses, the DC-link power $\mathrm{P}_{\mathrm{dc}}$ is equal to generation power $\mathrm{P}_{\mathrm{s}}$. In this case the DC-link voltage $\mathrm{V}_{\mathrm{dc}}$ dynamics is given by

$$
\begin{gathered}
\mathrm{i}_{\mathrm{dc}}=\mathrm{P}_{\mathrm{dc}} / \mathrm{V}_{\mathrm{dc}}=\mathrm{P}_{\mathrm{s}} / \mathrm{V}_{\mathrm{dc}}, \\
\dot{\mathrm{V}}_{\mathrm{dc}}=-(3 / 2) \mathrm{C}^{-1}\left(\left(\mathrm{u}_{\mathrm{d}} \mathrm{i}_{\mathrm{d}}+\mathrm{u}_{\mathrm{q}} \mathrm{i}_{\mathrm{q}}\right) / \mathrm{V}_{\mathrm{dc}}-\mathrm{i}_{\mathrm{L}}\right),
\end{gathered}
$$

where $\mathrm{C}$ is DC-link capacitance, $i_{\mathrm{dc}}$ denotes DC-link current from converter, $\mathrm{i}_{\mathrm{L}}$ is load current. that:

For the purpose of this study consider the IG and DC-link models according to (1), (5), and assume

A1. The stator currents, rotor speed and load current are available for measurement. All model parameters are known and constant.

A2. The DC-link voltage reference $\mathrm{V}_{\mathrm{dc}}^{*}>0$ and the rotor flux reference $\psi^{*}>0$ are constant.

Under these assumptions, the control problem is to design a flux-voltage controller which guarantees the following control objectives:

CO1. Asymptotic voltage regulation with all internal signals bounded, i.e. $\lim _{t \rightarrow \infty} \tilde{V}_{d c}=0$, where $\tilde{\mathrm{V}}_{\mathrm{dc}}=\mathrm{V}_{\mathrm{dc}}-\mathrm{V}_{\mathrm{dc}}^{*}$ is voltage regulation error.

CO2. Asymptotic flux regulation: $\lim _{t \rightarrow \infty} \tilde{\psi}=0$, where $\tilde{\psi}=\psi-\psi^{*}$ is a flux regulation error, $\psi$ denotes flux vector magnitude.

CO3. Asymptotic field orientation, i.e. $\lim _{t \rightarrow \infty} \psi_{\mathrm{q}}=0$.

CO4. Robustness to rotor resistance variations.

The following sections report the proposed solution to the formulated control problem.

Controller design. The main problem of the nonlinear controller design for system described by (1) and (5) is that the controls $\left(\mathrm{u}_{\mathrm{d}}, \mathrm{u}_{\mathrm{q}}\right)$ are present in both current and DC-link voltage dynamic equations. To overcome this problem, the following is assumed:

a) flux reference $\psi^{*}$ and primary mover speed $\omega$ are constant or slowly varying;

b) voltage subsystem dynamics is designed to be much slower than torque current $\mathrm{i}_{\mathrm{q}}$, providing the twotime scale separation properties for voltage and torque current controls.

Robust flux-current field oriented controller. Consider the direct field orientation control algorithm for system (1), which consists of:

- reduced order robust flux observer 


$$
\begin{aligned}
& \dot{\hat{\psi}}=-\alpha_{\mathrm{m}} \hat{\psi}+\alpha \mathrm{L}_{\mathrm{m}} \mathrm{i}_{\mathrm{d}}, \\
& \dot{\varepsilon}_{0}=\omega_{0}=\omega+\frac{\alpha \mathrm{L}_{\mathrm{m}} \mathrm{i}_{\mathrm{q}}}{\hat{\hat{\psi}}}+\frac{\gamma_{1} \beta_{\mathrm{m}} \omega \tilde{\tilde{\mathrm{i}}} \mathrm{d}}{\hat{\psi}}, \\
& \dot{\hat{\dot{\mathrm{i}}}}=-\gamma_{\mathrm{m}} \hat{\mathrm{i}}_{\mathrm{d}}+\omega_{0} \mathrm{i}_{\mathrm{q}}+\alpha_{\mathrm{m}} \beta_{\mathrm{m}} \hat{\psi}+\sigma_{\mathrm{m}}^{-1} \mathrm{u}_{\mathrm{d}}+\mathrm{k}_{1} \tilde{\tilde{\mathrm{i}}_{\mathrm{d}}} ;
\end{aligned}
$$

- flux controller

$$
\mathrm{i}_{\mathrm{d}}=\frac{1}{\alpha \mathrm{L}_{\mathrm{m}}}\left(\alpha_{\mathrm{m}} \psi^{*}+\dot{\psi}^{*}-\mathrm{k}_{\psi} \mathrm{e}_{\psi}-\mathrm{x}_{\psi}\right), \dot{\mathrm{x}}_{\psi}=\mathrm{k}_{\psi \mathrm{i}} \mathrm{e}_{\psi}
$$

- current controller

$$
u_{d}=\sigma_{m}\left(\gamma_{m} i_{d}^{*}-\omega_{0} i_{q}-\alpha_{m} \beta_{m} \psi^{*}-k_{i d} \tilde{i}_{d}+z_{d}\right), \dot{z}_{d}=-k_{i i} \tilde{i}_{d},
$$

where $\tilde{i}_{d}=i_{d}-i_{d}^{*}$ is d-axis current tracking error, $i_{d}^{*}$ is $i_{d}$ current reference, $\tilde{\tilde{i}}_{d}=i_{d}-\hat{i}_{d}$ is d-axis current observation error, $z_{d}$ denotes integral term of current controller, $e_{\psi}=\hat{\psi}-\psi^{*}$ is estimated flux tracking error, $\left(\mathrm{k}_{\mathrm{id}}, \mathrm{k}_{\mathrm{ii}}\right)>0$ are the current controller proportional and integral gains, $\left(\mathrm{k}_{\psi}, \mathrm{k}_{\psi \mathrm{i}}\right)>0$ are the flux controller proportional and integral gains, $\gamma_{1}>0$ is correction coefficient, $\mathrm{k}_{1}$ defines current observer gain.

It is important to note that the correction term $\gamma_{1} \beta_{\mathrm{m}} \omega \tilde{\tilde{\mathrm{i}}_{\mathrm{d}}} / \hat{\psi}$ in (6) provides the closed loop properties for flux subsystem and therefore the controller $(6)-(8)$ potentially has robustness properties with respect to the rotor resistance variations at non-zero machine speed. This property will be proven by results of the experimental study. can be written as

Applying field orientation controller (6) - (8) to model (1), the estimation-tracking error dynamics

$$
\begin{aligned}
& \dot{\mathrm{x}}_{\psi}=-\mathrm{k}_{\psi \mathrm{i}} \mathrm{e}_{\psi}, \\
& \dot{\mathrm{e}}_{\psi}=-\mathrm{k}_{\psi 1} \mathrm{e}_{\psi}+\mathrm{x}_{\psi}+\alpha \mathrm{L}_{\mathrm{m}} \tilde{\mathrm{i}}_{\mathrm{d}}, \\
& \dot{\mathrm{Z}}_{\mathrm{d}}=-\mathrm{k}_{\mathrm{ii}} \tilde{\mathrm{i}}_{\mathrm{d}}, \\
& \dot{\mathrm{i}}_{\mathrm{d}}=-\mathrm{k}_{\mathrm{id} 1} \tilde{\mathrm{i}}_{\mathrm{d}}+\mathrm{z}_{\mathrm{d}}+\alpha_{\mathrm{m}} \beta_{\mathrm{m}} \tilde{\Psi}_{\mathrm{d}}+\omega \beta_{\mathrm{m}} \tilde{\Psi}_{\mathrm{q}}, \\
& \dot{\tilde{\Psi}}_{\mathrm{d}}=-\alpha_{\mathrm{m}} \tilde{\Psi}_{\mathrm{d}}+\omega_{\mathrm{s}} \tilde{\Psi}_{\mathrm{q}}, \\
& \dot{\tilde{\Psi}}_{\mathrm{q}}=-\alpha_{\mathrm{m}} \tilde{\Psi}_{\mathrm{q}}-\omega_{\mathrm{s}} \tilde{\Psi}_{\mathrm{d}}-\gamma_{1} \omega \beta_{\mathrm{m}} \tilde{\mathrm{i}_{\mathrm{d}}}, \\
& \dot{\tilde{\dot{\mathrm{i}}}}_{\mathrm{d}}=-\mathrm{k}_{0} \tilde{\tilde{\mathrm{i}}}_{\mathrm{d}}+\alpha_{\mathrm{m}} \beta_{\mathrm{m}} \tilde{\Psi}_{\mathrm{d}}+\omega \beta_{\mathrm{m}} \tilde{\Psi}_{\mathrm{q}},
\end{aligned}
$$

where $\tilde{\psi}_{\mathrm{d}}=\psi_{\mathrm{d}}-\psi^{*}, \tilde{\psi}_{\mathrm{q}}=\psi_{\mathrm{q}}$ are the flux estimation errors, $\mathrm{k}_{\psi 1}=\alpha_{\mathrm{m}}+\mathrm{k}_{\psi}, \mathrm{k}_{\mathrm{id} 1}=\gamma_{\mathrm{m}}+\mathrm{k}_{\mathrm{id}}, \mathrm{k}_{0}=\gamma_{\mathrm{m}}+\mathrm{k}_{1}$.

Applying Lyapunov analysis, it can be shown that estimation subsystem (10) is globally exponentially stable if condition $\alpha_{\mathrm{m}} \mathrm{k}_{0}>\gamma_{1}\left(\alpha \mathrm{L}_{\mathrm{m}} \beta_{\mathrm{m}}\right)^{2} / 4$ is satisfied. Hence, estimation errors $\left(\tilde{\Psi}_{\mathrm{d}}, \tilde{\Psi}_{\mathrm{q}}, \tilde{\tilde{\mathrm{d}}}_{\mathrm{d}}\right)$ exponentially converge to zero independently on flux regulation dynamics. From the other hand, subsystem (9) is linear and asymptotically stable for any values of tuning gains $\left(\mathrm{k}_{\mathrm{id}}, \mathrm{k}_{\mathrm{ii}}\right)>0$ and $\left(\mathrm{k}_{\psi}, \mathrm{k}_{\psi \mathrm{i}}\right)>0$. As far as subsystems (10) and (9) are connected in series, we can conclude that equilibrium point $\tilde{\mathbf{x}}_{1}=\left(\mathrm{x}_{\psi}, \mathrm{e}_{\psi}, \mathrm{z}_{\mathrm{d}}, \tilde{\mathrm{i}}_{\mathrm{d}}, \tilde{\Psi}_{\mathrm{d}}, \tilde{\Psi}_{\mathrm{q}}, \tilde{\tilde{\mathrm{i}}}_{\mathrm{d}}\right)=\mathbf{0}$ of composite system is globally exponentially stable. This implies that asymptotic field orientation and asymptotic flux regulation are achieved. Hence, the control objectives (CO2) and $(\mathrm{CO} 3)$ are met.

Feedback linearizing voltage controller. For q-axis current regulation let consider the following current controller

$$
\mathrm{u}_{\mathrm{q}}=\sigma_{\mathrm{m}}\left(\gamma_{\mathrm{m}} \mathrm{i}_{\mathrm{q}}^{*}+\omega_{0} \dot{\mathrm{i}}_{\mathrm{d}}+\beta_{\mathrm{m}} \omega \psi^{*}-\mathrm{k}_{\mathrm{iq}} \tilde{\mathrm{i}}_{\mathrm{q}}+\mathrm{z}_{\mathrm{q}}\right), \dot{\mathrm{z}}_{\mathrm{q}}=-\mathrm{k}_{\mathrm{ii}} \tilde{\mathrm{i}}_{\mathrm{q}},
$$

where $\tilde{i}_{q}=i_{q}-i_{q}^{*}$ is $q$-axis current tracking error, $i_{q}^{*}$ denotes $i_{q}$ current reference, $z_{q}$ is integral term of current controller, $\mathrm{k}_{\mathrm{iq}}$ is proportional gain of current controller. 
For $\psi^{*}=$ const, $i_{d}^{*}=$ const and assuming that $i_{q}^{*}$ is slowly varying, one can state that $i_{d}^{*}=i_{q}^{*}=0$. Under these conditions, $\mathrm{q}$-axis current error dynamic can be written as

$$
\dot{\tilde{\mathbf{x}}}_{2}=\mathbf{A}_{2} \tilde{\mathbf{x}}_{2}+\mathbf{B}(\mathrm{t}) \tilde{\mathbf{x}}_{1},
$$

where $\tilde{\mathbf{x}}_{2}=\left(\mathrm{z}_{\mathrm{q}}, \tilde{\mathrm{i}}_{\mathrm{q}}\right)^{\mathrm{T}}, \mathbf{A}_{2}=\left[\begin{array}{cc}0 & \mathrm{k}_{\mathrm{ii}} \\ -1 & -\mathrm{k}_{\mathrm{iq} 1}\end{array}\right], \mathrm{k}_{\mathrm{iq} 1}=\gamma_{\mathrm{m}}+\mathrm{k}_{\mathrm{iq}}$ and $\mathbf{B}(\mathrm{t})=\left[\begin{array}{ccccccc}0 & 0 & 0 & 0 & 0 & 0 & 0 \\ 0 & 0 & 0 & 0 & -\beta_{\mathrm{m}} \omega & \alpha \beta_{\mathrm{m}} & 0\end{array}\right]$.

As far as constant matrix $\mathbf{A}_{2}$ is Hurwitz, the nominal dynamics of the subsystem (12) (if $\mathbf{B}(\mathrm{t})=0$ ) is linear and asymptotically stable. Matrix $\mathbf{B}(\mathrm{t})$ is bounded, and therefore composite system (12), (9), (10) is exponentially stable. Hence, the equilibrium point

$$
\tilde{\mathbf{x}}=\left(\tilde{\mathbf{x}}_{1}^{\mathrm{T}}, \tilde{\mathbf{x}}_{2}^{\mathrm{T}}\right)^{\mathrm{T}}=\mathbf{0}
$$

is exponentially stable.

Taking into account (13), the applied voltages become

$$
\begin{aligned}
& \mathrm{u}_{\mathrm{d}}=\mathrm{R}_{1} \mathrm{i}_{\mathrm{d}}^{*}-\sigma_{\mathrm{m}} \omega_{0} \mathrm{i}_{\mathrm{q}}^{*}, \\
& \mathrm{u}_{\mathrm{q}}=\mathrm{R}_{1} \mathrm{i}_{\mathrm{q}}^{*}+\alpha \mathrm{L}_{\mathrm{m}}^{2} \mathrm{i}_{\mathrm{q}}^{*} / \mathrm{L}_{2}+\sigma_{\mathrm{m}} \omega_{0} i_{\mathrm{d}}^{*}+\mathrm{L}_{\mathrm{m}} \omega \psi^{*} / \mathrm{L}_{2} .
\end{aligned}
$$

Using (14), the IG output power is derived as

$$
\mathrm{P}_{\mathrm{s}}=-\frac{3}{2}\left(\mathrm{R}_{1}\left(\mathrm{i}_{\mathrm{d}}^{* 2}+\mathrm{i}_{\mathrm{q}}^{* 2}\right)+\mathrm{R}_{2} \frac{\mathrm{L}_{\mathrm{m}}^{2}}{\mathrm{~L}_{2}^{2}} \mathrm{i}_{\mathrm{q}}^{* 2}+\frac{\mathrm{L}_{\mathrm{m}}}{\mathrm{L}_{2}} \omega \psi^{*} \mathrm{i}_{\mathrm{q}}^{*}\right)
$$

According to (15), the output power consists of three components: active losses in the stator (proportional to $\mathrm{R}_{1}$ ), active rotor losses (proportional to $\mathrm{R}_{2}$ ) and input mechanical power

$$
\mathrm{P}_{\mathrm{m}}=\frac{3}{2} \frac{\mathrm{L}_{\mathrm{m}}}{\mathrm{L}_{2}} \omega \psi^{*} \mathrm{i}_{\mathrm{q}}^{*}=\frac{3}{2} \frac{\mathrm{L}_{\mathrm{m}}}{\mathrm{L}_{2}} \omega \psi \mathrm{i}_{\mathrm{q}}=\mathrm{T} \omega
$$

where $\mathrm{T}$ is electromagnetic torque.

From equations (4), (5), (15) one can derive the DC-link voltage regulation error dynamics for $\mathrm{V}_{\mathrm{dc}}^{*}=$ const as

$$
\dot{\tilde{\mathrm{V}}}_{\mathrm{dc}}=-\frac{1}{\mathrm{CV}_{\mathrm{dc}}}\left(\frac{3}{2}\left(\mathrm{R}_{1}\left(\frac{\psi^{* 2}}{\mathrm{~L}_{\mathrm{m}}^{2}\left(\mathrm{i}_{\mathrm{m}}\right)}+\mathrm{i}_{\mathrm{q}}^{* 2}\right)+\mathrm{R}_{2} \frac{\mathrm{L}_{\mathrm{m}}^{2}}{\mathrm{~L}_{2}^{2}} \mathrm{i}_{\mathrm{q}}^{* 2}+\frac{\mathrm{L}_{\mathrm{m}}}{\mathrm{L}_{2}} \omega \psi^{*} \mathrm{i}_{\mathrm{q}}^{*}\right)+\mathrm{V}_{\mathrm{dc}} \mathrm{i}_{\mathrm{L}}\right) .
$$

From the right hand side of (17) it follows that the expression in brackets is power balance equation under conditions (13), (14).

For the dynamics (17), a feedback linearizing voltage controller has been designed as shown in [14],

$$
i_{\mathrm{q}}^{*}=\frac{-\frac{\mathrm{L}_{\mathrm{m}}}{\mathrm{L}_{2}} \omega \psi^{*}+\sqrt{\left(\frac{\mathrm{L}_{\mathrm{m}}}{\mathrm{L}_{2}} \omega \psi^{*}\right)^{2}-4\left(\alpha \frac{\mathrm{L}_{\mathrm{m}}^{2}}{\mathrm{~L}_{2}}+\mathrm{R}_{1}\right) \rho}}{2\left(\alpha \frac{\mathrm{L}_{\mathrm{m}}^{2}}{\mathrm{~L}_{2}}+\mathrm{R}_{1}\right)}, \rho=\mathrm{R}_{1} \frac{\psi^{* 2}}{\mathrm{~L}_{\mathrm{m}}^{2}\left(\mathrm{i}_{\mathrm{m}}\right)}+\frac{2}{3} \mathrm{~V}_{\mathrm{dc}}\left(\mathrm{i}_{\mathrm{L}}+\mathrm{C}\left(-\mathrm{k}_{\mathrm{v}} \tilde{\mathrm{V}}_{\mathrm{dc}}+\mathrm{x}_{\mathrm{v}}\right)\right),
$$
form:

The resulting voltage dynamics is a second order linear asymptotically stable system in the following

$$
\dot{\tilde{\mathrm{V}}}_{\mathrm{dc}}=-\mathrm{k}_{\mathrm{v}} \tilde{\mathrm{V}}_{\mathrm{dc}}+\mathrm{x}_{\mathrm{v}}, \dot{\mathrm{x}}_{\mathrm{v}}=-\mathrm{k}_{\mathrm{vi}} \tilde{\mathrm{V}}_{\mathrm{dc}}
$$

where $\left(\mathrm{k}_{\mathrm{v}}, \mathrm{k}_{\mathrm{vi}}\right)>0$ are the proportional and integral gains of the voltage controller.

The block diagram of control system is shown in Fig. 2.

Under condition of constant or slowly varying $\mathrm{V}_{\mathrm{dc}}^{*}, \mathrm{i}_{\mathrm{L}}$ and $\psi^{*}$ dynamics of the voltage control loop can be designed to be much slower than current dynamics (12), (13) providing the two-time scale separation to justify common assumption for current-fed IG control. Under these conditions, the system error dynamics are given by (19) and (12) allowing for separated considerations of weakly coupled two subsystems, namely - the voltage control loop (19) and the q-axis current error dynamics (12). The system tuning is provided by selection of proportional and integral gains for voltage and current controllers as considered in [14], [18]. 
From the above stability analysis, it follows that the local asymptotic regulation $\lim _{t \rightarrow \infty} \tilde{V}_{d c}=0$ is obtained, therefore control objectives $\mathrm{CO} 1-\mathrm{CO} 3$ are locally achieved if

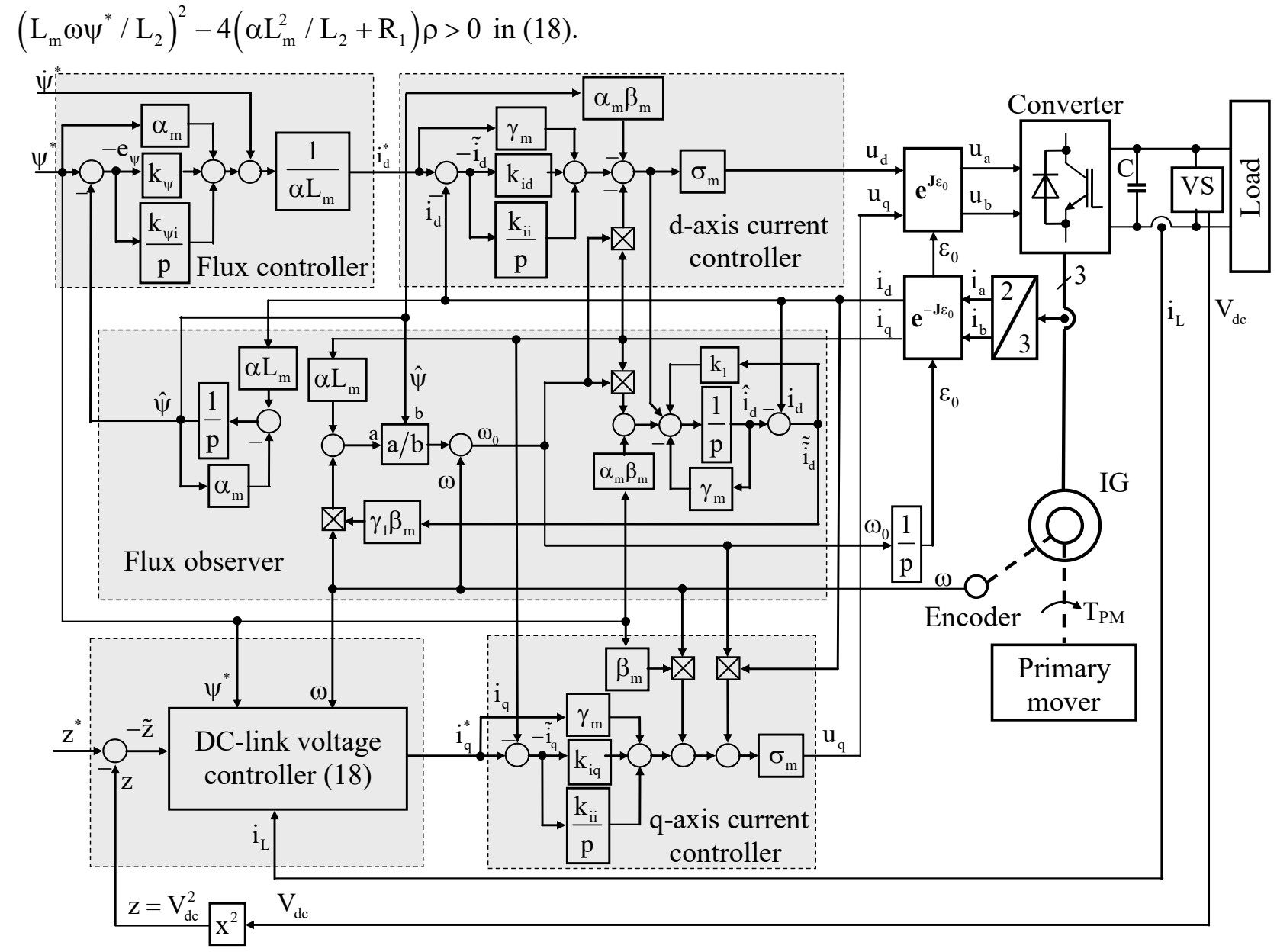

Fig. 2

Remark. For $\mathrm{i}_{\mathrm{L}}=$ const compensation term $\mathrm{i}_{\mathrm{L}}$ may be removed from the feedback linearizing controller (18) leaving $i_{L}$ compensation for the integral action of the controller.

Experimental results. Experimental studies were carried out using the Rapid Prototyping Station (RPS). As shown in Fig. 3, the RPS included: 1) induction generator with rated output power 1.9kW, rated phase voltage $220 \mathrm{~V}(\mathrm{rms})$, rated phase current $5 \mathrm{~A}(\mathrm{rms}), \mathrm{R}_{1}=3.5 \mathrm{Ohm}, \mathrm{R}_{2}=2.1 \mathrm{Ohm}, \mathrm{L}_{1}=0.2655 \mathrm{H}$, $\mathrm{L}_{2}=0.2655 \mathrm{H}, \mathrm{L}_{\mathrm{m}}=0.257 \mathrm{H}, \mathrm{p}_{\mathrm{n}}=2 ; 2$ ) induction motor coupled with IG and used as a primary mover; 3) 20 A and $380 \mathrm{~V}$ three-phase PWM controlled converter operated at $5 \mathrm{kHz}$ switching frequency; 4) commutated load resistance $\mathrm{R}_{\mathrm{L}}$; 5) DSP TMS320F28335-based controller for implementation of control algorithms with programmable tracing of selected variables; 6) personal computer for processing, programming, interactive

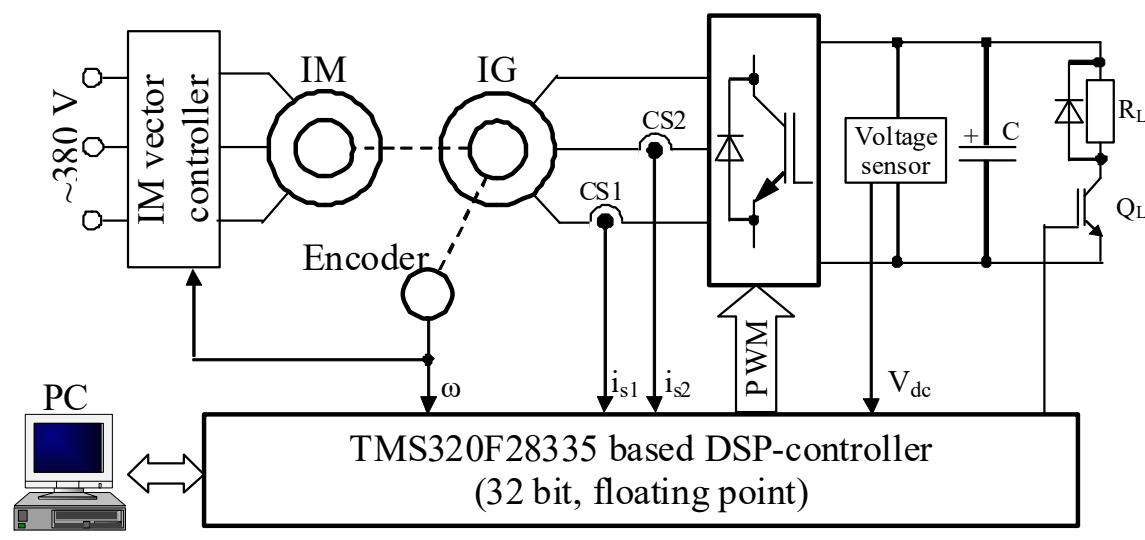

Fig. 3 oscilloscope, data acquisition, etc. The motor speed was measured by 1024 ppr optical encoder; the DClink capacitance $\mathrm{C}=1000 \mu \mathrm{F}$ and sampling time was set at $200 \mu \mathrm{sec}$.

During all experiments, the rotor speed was stabilized by a vector control system, which acted as a primary mover. The goal of experimental tests was to investigate the dynamic performance and efficiency of the two control strategies, namely: indirect field- 
oriented control (IFOC) in standard configuration [14]; robust direct field-oriented voltage controller (RDFOC), given by equations (6), (8), (11), (18).

In order to compare the dynamic performance of IFOC and RDFOC, the compensation of load current $i_{L}$ was eliminated from the RDFOC algorithm.

Tuning parameters were set as follows: $\mathrm{k}_{\mathrm{id}}=\mathrm{k}_{\mathrm{iq}}=800, \mathrm{k}_{\mathrm{ii}}=\mathrm{k}_{\mathrm{iq} 1}^{2} / 4, \mathrm{k}_{1}=500, \gamma_{1}=0.001$, $\gamma_{2}=0.025, \mathrm{k}_{\mathrm{v}}=125, \mathrm{k}_{\mathrm{vi}}=\mathrm{k}_{\mathrm{v}}^{2} / 2$ for RDFOC; and $\mathrm{k}_{\mathrm{v} 1}=0.18, \mathrm{k}_{\mathrm{vil}}=11$ for IFOC. Both controllers were tuned to provide the same performance of the voltage control loops when the system operated at speed $140 \mathrm{rad} / \mathrm{s}$.

At the first stage, the comparative tests were performed for two constant shaft speeds $\omega=140 \mathrm{rad} / \mathrm{s}$ and $\omega=100 \mathrm{rad} / \mathrm{s}$ using operation sequence, as shown in Fig. 4;

- before the test DC-link capacitor was charged to $120 \mathrm{~V}$, rotor speed was stabilized by primary mover at $\omega=25 \mathrm{rad} / \mathrm{s}$;

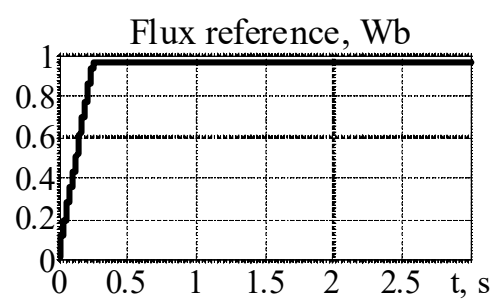

Voltage references, $\mathrm{V}$ and

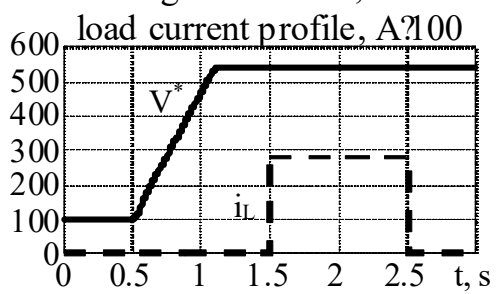

Fig. 4
- initial time interval $0 \ldots 0.25 \mathrm{~s}$ was used to excite the generator by applying a flux reference trajectory reported in Fig. 4 with $\psi^{*}(0)=0.02 \mathrm{~Wb}$ and reached the value of $0.96 \mathrm{~Wb}$;

- starting at $\mathrm{t}=0.5 \mathrm{~s}$, primary mover speed was increased to predefined value $(140 \mathrm{rad} / \mathrm{s}$ or $100 \mathrm{rad} / \mathrm{s}$ );

- during IG acceleration, the voltage reference was increased together with rotor speed up to $\mathrm{V}^{*}=540 \mathrm{~V}$;

- at time $\mathrm{t}=1.5 \mathrm{~s}$ load current $2.8 \mathrm{~A}$ was applied and at $\mathrm{t}=2.5 \mathrm{~s}$ it was removed; such a load current corresponds to the rated mechanical power at machine shaft.
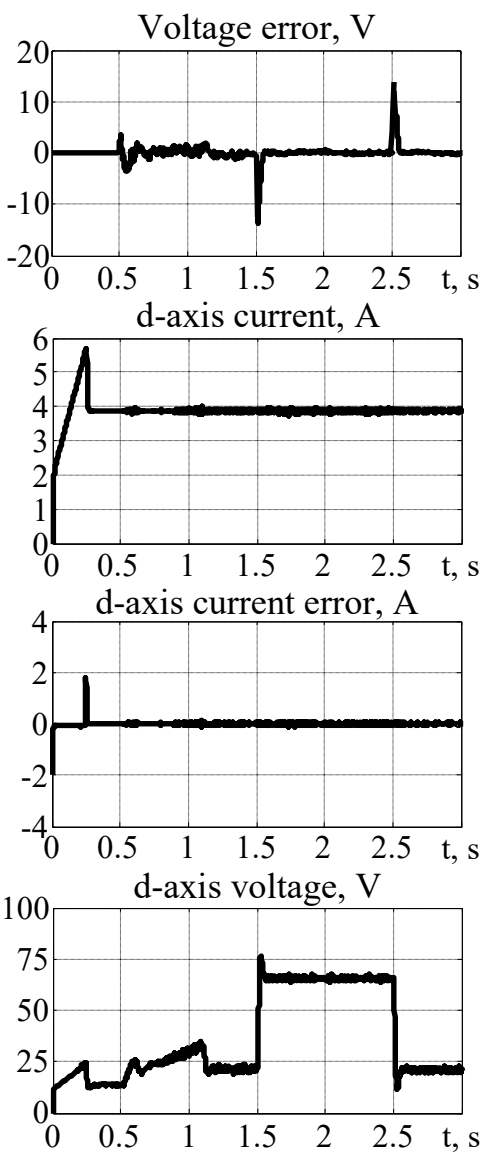

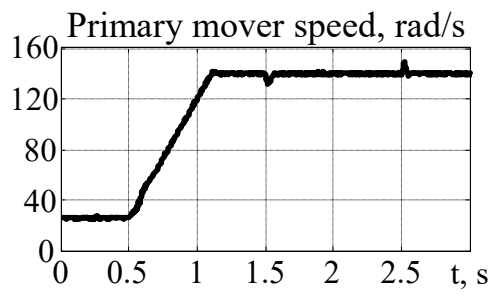

q-axis current, $A$
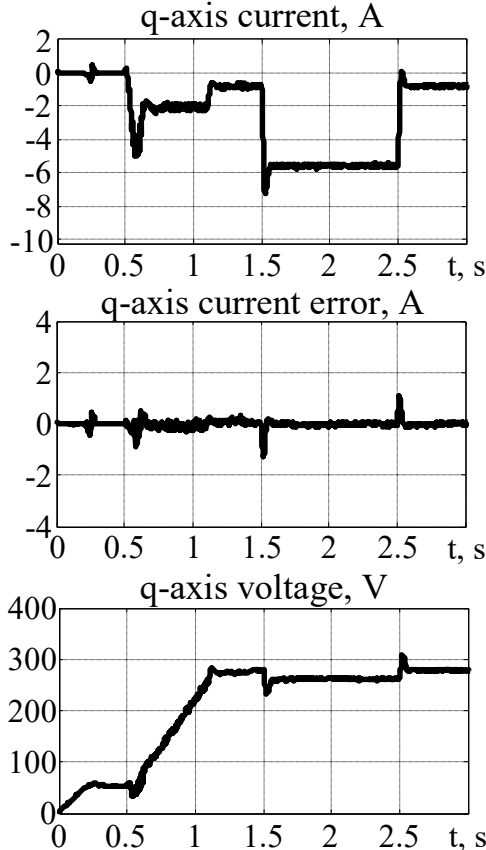

It is necessary to note, that selection of the initial values of the voltage and flux at different speeds is a separate task, which is considered in [19]. During experimental investigations, initial values of the voltage, speed and flux are selected according to physical capabilities of the generation system to provide IG excitation during start-up.

Experimental results for RDFOC are shown in Fig. 5. As it follows from these results, the proposed control algorithm provides asymptotic field orientation (condition of $\mathrm{CO} 3$ ) and flux-voltage regulation (conditions of $\mathrm{CO} 1$ and $\mathrm{CO} 2$ are met).

In order to compare the dynamic behavior of the IFOC and RDFOC at different speeds an additional test was performed for IG operation at $\omega=140 \mathrm{rad} / \mathrm{s}$ and $\omega=100 \mathrm{rad} / \mathrm{s}$. Load current for these tests was reduced to $\mathrm{i}_{\mathrm{L}}=1.8 \mathrm{~A}$ in order to provide machine operation with rated current at low speed $(\omega=100 \mathrm{rad} / \mathrm{s})$. Transients for both controllers at different speed are depicted in Fig. 6. 
From these results, it follows that both controllers provide the same dynamic performance when the system operates at speed 140 rad/s. Performances of the proposed controller are independent from the generator speed. At the same time, the dynamics of the standard controller deteriorates when $\omega=100 \mathrm{rad} / \mathrm{s}$ : the dynamic error increases from $8 \mathrm{~V}$ up to $12 \mathrm{~V}$ for the given load.

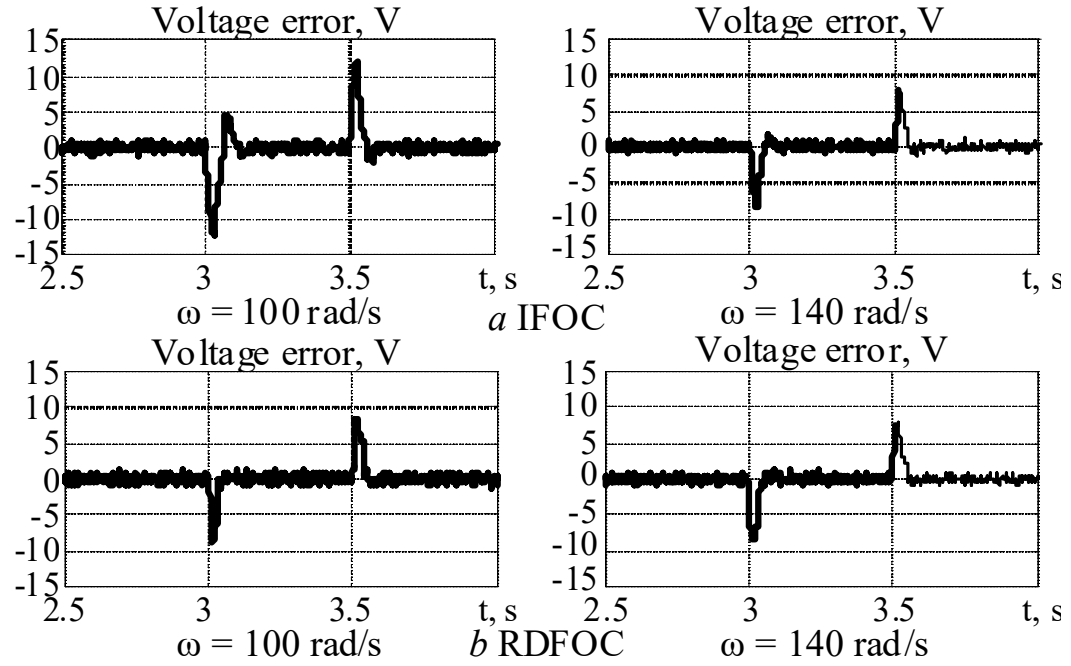

Fig. 6

A second set of experiments was undertaken to compare the dynamic performance of the two controllers, when parameter $\hat{\mathrm{R}}_{2}$ used in the control algorithm is different from the actual one.

Fig. 7, a shows the transients with the standard control obtained for $\hat{R}_{2}=1.6 \mathrm{R}_{2}$ and $\hat{\mathrm{R}}_{2}=0.6 \mathrm{R}_{2}$ respectively (above this variation range IFOC becomes unstable). During these tests loading time was extended up to $3.5 \mathrm{~s}$ to achieve steady state operation conditions. As shown in Fig. 7, $a$, the significant degradation of the transient performance occurs for parameter $\hat{\mathrm{R}}_{2}$ higher than the rated value for IFOC. The steady state value of $i_{q}$ axis current

is almost $20 \%$ greater than the nominal regime. When $\hat{\mathrm{R}}_{2}$ is lower than original one, voltage regulation dynamics also deteriorate and torque producing current increases up to $40 \%$. As discussed in [16], [17], the inaccurate value of rotor resistance with $\hat{R}_{2}>R_{2}$ produces the reduction of the rotor flux magnitude. If $\hat{\mathrm{R}}_{2}<\mathrm{R}_{2}$, the motor electromagnetic system enters the saturation region, causing an increase of the stator current magnitude. Due to the effect of saturation, the IG operates with almost constant flux modulus, but with incorrect field orientation.
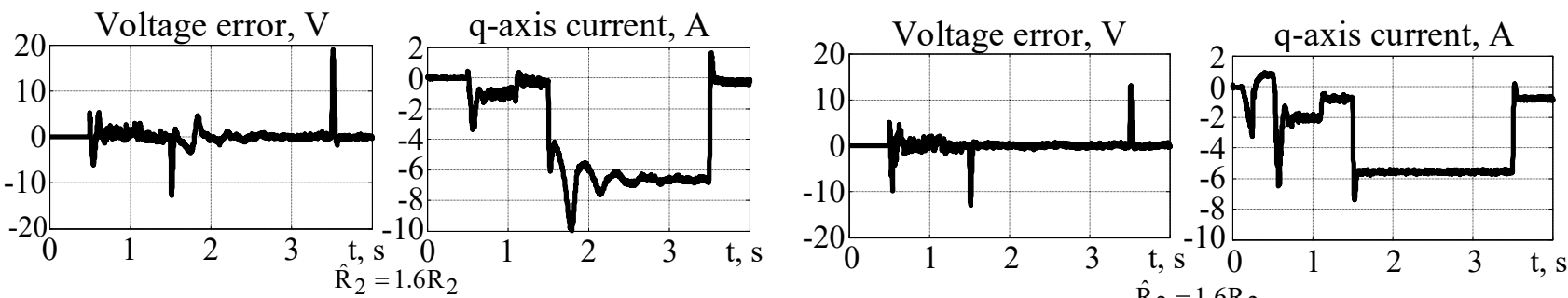

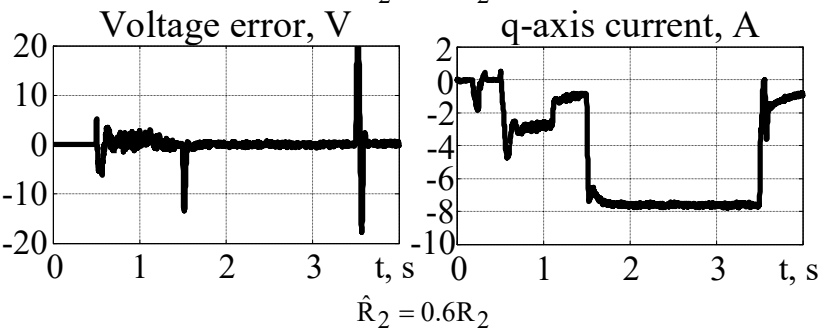

a IFOC

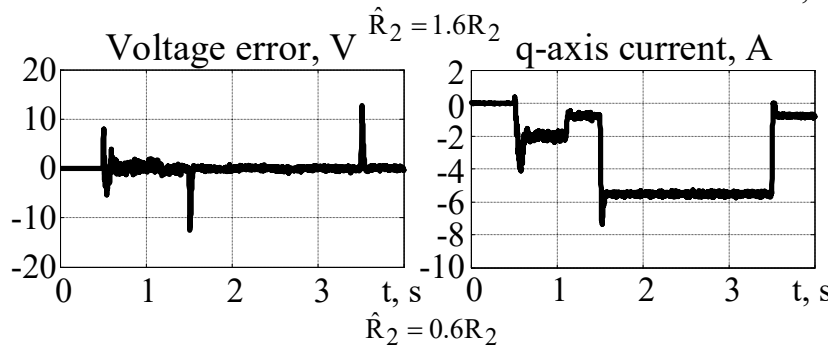

b $\mathrm{RDFOC}$

Fig. 7

The results of the same test for RDFOC are reported in Fig. 7, $b$. Comparison of results in Fig. 7, $a$ and Fig. 7, $b$ shows that the developed direct field-oriented controller demonstrates strong robustness properties with respect to rotor resistance variations. No significant difference during load current compensation can be noted in transients for nominal (Fig. 5) and perturbed (Fig. 7) conditions.

A third set of experiments was undertaken to compare the system efficiency under steady-state operation. The comparison was referred to steady state behavior of the two controllers at fixed speed of 140 
$\mathrm{rad} / \mathrm{s}$. The rated current was applied to verify how stator current magnitude and estimated input mechanical power varies when wrong values of the parameter $\hat{R}_{2}$ are used in both control algorithms. During the experiments, $\mathrm{i}_{\mathrm{d}}$ current was set to the rated value in order to get the nominal rotor flux. The steady-state regulation errors $\tilde{V}_{\mathrm{dc}}$ and $\tilde{\mathrm{i}}_{\mathrm{d}}$ are negligible for both algorithms.

The tests were conducted in the following way. Constant load current equivalent to rated power $\mathrm{P}_{\mathrm{dc}}=1.9 \mathrm{~kW}$ was imposed. Different values of parameter $\hat{\mathrm{R}}_{2}$ were used in both control algorithms and for each value, the steady state current magnitude and mechanical power of the primary mover were recorded. In Fig. 8 the current magnitude and mechanical power $\mathrm{P}_{\mathrm{m}}$ of the standard controller are shown as dashed lines, while the same variables of the proposed controller are reported with solid lines.

The experimental results in Fig. 8 show that the RDFOC controller is capable of keeping an almost constant stator current magnitude and input mechanical power even with large $\hat{\mathrm{R}}_{2}$-parameter error. In contrast, the current magnitude imposed by the IFOC controller and required mechanical power considerably increase when an inaccurate $\hat{R}_{2}$ is used. As a result, proposed controller provides efficiency stabilization as it shown in Fig. 9. In worst case, when $\hat{\mathrm{R}}_{2}=1.5 \mathrm{R}_{2}$, efficiency of the RDFOC controller is approximately on $10 \%$ higher in comparison to IFOC controller.
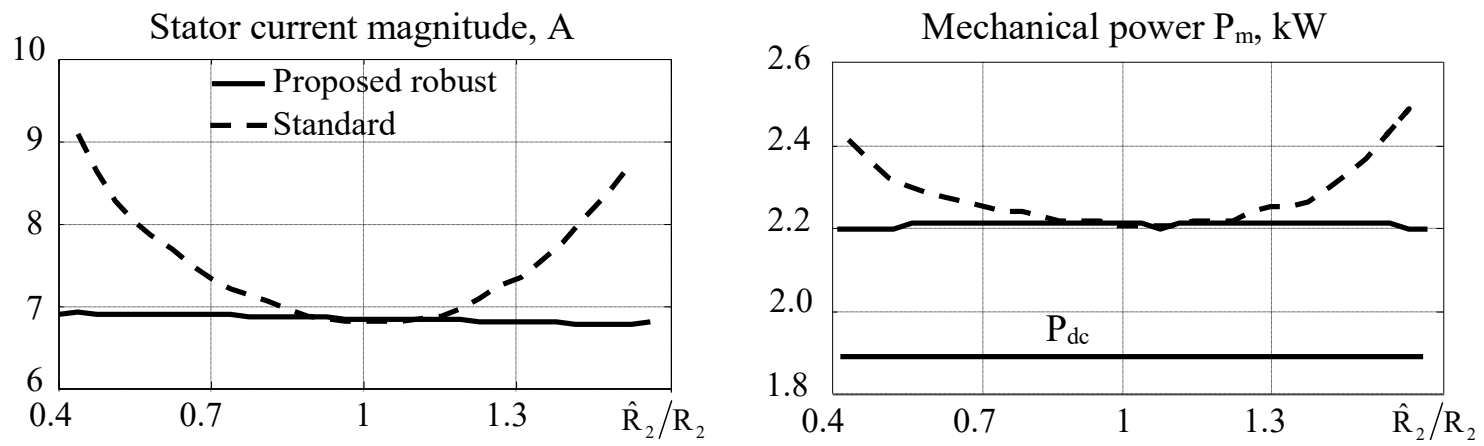

Fig. 8

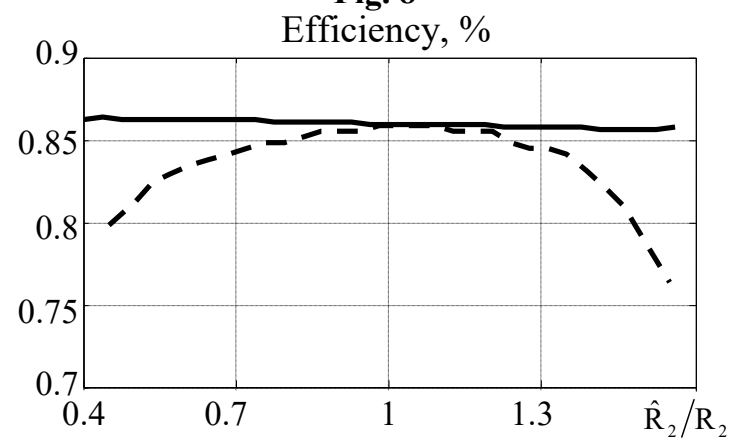

Fig. 9

Conclusions. In this paper, a novel robust direct field-oriented controller for standalone induction generator has been designed and experimentally verified. A nonlinear control algorithm guarantees local asymptotic voltage-flux regulation under variable speed and flux conditions. In contrast to existing solutions, the flux subsystem is designed using Lyapunov's $2^{\text {nd }}$ method and employs an estimated flux current error feedback. The proposed design guarantees an exponential convergence of flux subsystem regulation errors to zero, decoupling from the voltage control, improved robustness with respect to the rotor resistance variation leading to improved dynamic performance and efficiency of the electromechanical energy conversion.

An intensive experimental study of the proposed solution and comparison against the standard indirect field-oriented voltage control system with PI voltage controller clearly demonstrates that a significant improvement in both dynamic performance and energy conversion efficiency is achieved. The controller proposed in this paper is therefore suitable for energy generation systems with variable speed operation. 
1. Simoes M. G., Farret F. A. Modeling and analysis with induction generators. $3^{\text {rd }}$ edition. Boca Raton, Florida, USA: CRC Press, 2014. 468 p.

2. Cardenas R., Pena R., Alepuz S., Asher G. Overview of control systems for the operation of DFIGs in wind energy applications. IEEE Transactions on Industrial Electronics. 2013. Vol. 60. No. 7. Pp. 2776-2798. DOI: https://doi.org/10.1109/TIE.2013.2243372

3. Carunaiselvane C., Chelliah T. R. Present trends and future prospects of asynchronous machines in renewable energy systems. Renewable and Sustainable Energy Reviews. 2017. Vol. 74. Pp. 1028-1041. DOI: https://doi.org/10.1016/j.rser.2016.11.069

4. Wu B. Lang Y. Zargari N. Kouro S. Power conversion and control of wind energy systems. Wiley-IEEE Press, $2011.480 \mathrm{p}$.

5. Feehally T., Apsley J. M. The doubly fed induction machine as an aero generator. IEEE Transactions on Industry Applications. 2015. Vol. 51. No. 4. Pp. 3462-3471. DOI: https://doi.org/10.1109/TIA.2015.2413957

6. Lyra R. O. C., Silva S. R. , Cortizo P. C. Direct and indirect flux control of an isolated induction generator. Proc. International Conference on Power Electronics and Drive Systems (PEDS 95). Singapore, 21-24 February 1995. Vol. 1. Pp. 140-145. DOI: https://doi.org/10.1109/PEDS.1995.404933

7. Levi E., Liao Y. Rotor flux oriented induction machine as a DC power generator. Proc. 8th European Conference on Power Electronics and Applications. EPE99. Lausanne, Switzerland, 7-9 September 1999. CD-ROM. Pp. 1-8.

8. Cimuca G., Breban S., Radulescu M. M., Saudemont C., Robyns B. Design and control strategies of an inductionmachine-based flywheel energy storage system associated to a variable-speed wind generator. IEEE Transactions on Energy Conversion. 2010. Vol. 25. No. 2. Pp. 526-534. DOI: https://doi.org/10.1109/TEC.2010.2045925

9. Seyoum D., Rahman M. F., Grantham C. Terminal voltage control of a wind turbine driven isolated induction generator using stator oriented field control. Proc. 18th Annual IEEE Applied Power Electronics Conference and Exposition. APEC03. Miami Beach, FL, USA, 9-13 February 2003. Vol. 2. Pp. 846-852. DOI: https://doi.org/10.1109/APEC.2003.1179315

10. Leidhold R., Garcia G., Valla M. I. Field-oriented controlled induction generator with loss minimization. IEEE Transactions on Industrial Electronics. 2002. Vol. 49. No. 1. Pp. 147-156. DOI: https://doi.org/10.1109/41.982258

11. Hazra S., Sensarma P. S. DC bus voltage build up and control in stand-alone wind energy conversion system using direct vector control of SCIM. Proc. 34th Annual Conference of IEEE Industrial Electronics IECON08. Orlando, FL, USA, 10-13 November 2008. Pp. 2143-2148. DOI: https://doi.org/10.1109/IECON.2008.4758288

12. Meddouri S., Rastegarpour S., Ferrarini L., Idjdarene K. A nonlinear Lyapunov-based control for an autonomous variable-speed wind turbine. Proc. 6th International Conference on Clean Electrical Power ICCEIP17. Santa Margherita Ligure, Italy, 27-29 June 2017. Pp. 430-436. DOI: https://doi.org/10.1109/ICCEP.2017.8004723

13. Bozhko S., Peresada S., Kovbasa S., Zhelinskyi M. Robust indirect field oriented control of induction generator. Proc. International Conference on Electrical Systems for Aircraft, Railway, Ship Propulsion and Road Vehicles \& International Transportation Electrification Conference ESARS-ITEC2016. Toulouse, France, 2-4 November 2016. Pp. 1-6. DOI: https://doi.org/10.1109/ESARS-ITEC.2016.7841421

14. Peresada S., Zhelinskyi M., Kovbasa S., Korol S. Indirect field oriented control of the saturated induction generators with linear PI regulators. Proc. 6th International Conference on Energy Smart Systems ESS2019. Kyiv, Ukraine, 1719 April 2019. Pp. 138-143. DOI: https://doi.org/10.1109/ESS.2019.8764203

15. Levi E. Impact of cross-saturation on accuracy of saturated induction machine models. IEEE Transactions on Energy Conversion. 1997. Vol. 12. No. 3. Pp. 211-216. DOI: https://doi.org/10.1109/60.629705

16. Peresada S., Tonielli A. High-performance robust speed-flux tracking controller for induction motor. Adaptive Control Signal Processing. 2000. Vol. 14. Pp. 177-200. DOI: https://doi.org/10.1002/(SICI)10991115(200003/05)14:2/3\%3C177::AID-ACS579\%3E3.0.CO;2-2

17. Peresada S., Tilli A., Tonielli A. Theoretical and experimental comparison of indirect field-oriented controllers for induction motors. IEEE Transactions on Power Electronics. 2003. Vol. 18. No. 1. Pp. 151-163. DOI: https://doi.org/10.1109/TPEL.2002.807123

18. Peresada S., Kovbasa S., Korol S., Zhelinskyi N. Feedback linearizing field-oriented control of induction generator: theory and experiments. Tekhnichna elektrodynamika. 2017. No 2. Pp. 48-56. DOI: https://doi.org/10.15407/techned2017.02.048

19. Zhelinskyi M. M. Vector control system of induction generator with robustness properties to parametric perturbations: Cand. techn. sci. diss. 05.09.03. National Technical University of Ukraine Igor Sikorsky Kyiv Polytechnic Institute. Kyiv, Ukraine. 2021. 216 p. (Ukr). 
УДК 681.5: 62-83

\section{АЛГОРИТМ РОБАСТНОГО ПРЯМОГО ВЕКТОРНОГО КЕРУВАННЯ АСИНХРОННИМ ГЕНЕРАТОРОМ}

С.М. Пересада ${ }^{1}$, докт. техн. наук, С.В. Божко ${ }^{2}$, канд. техн. наук, С.М. Ковбаса ${ }^{1}$, докт. техн. наук, С.О. Ніконенко 1

${ }^{1}$ НТУУ «Київський політехнічний інститут ім. Ігоря Сікорського», пр. Перемоги, 37, Київ, 03056, Україна

e-mail: sergei.peresada@gmail.com

${ }^{2}$ Університет Ноттінгема, NottinghamNG7 2RD, Великобританія

У роботі розроблено новий робастний алгоритм прямого полеорієнтованого векторного керування автономними асинхронними генераторами (АГ). Запропонований регулятор використовує концепцію прямого полеорієнтування та забезпечує асимптотичне регулювання модуля вектора потокозчеплення ротора $i$ напруги ланки постійного струму за умови, щзо навантаження в ланці постійного струму постійне або змінюється повільно. Підсистема регулювання потокозчеплення, розроблена з використанням другого методу Ляпунова, на відміну від стандартних конструкиій, має властивості замкненого контуру i, отюе, вона є робастною до варіацій опору ротора. Для проектування підсистеми напруги використовується підхід декомпозиції на основі розділення в часі динаміки напруги та моментної складової струму статора. Лінеаризуючий зворотним зв'язком регулятор напруги розроблено з використанням рівняння балансу потужності АГ в усталеному режимі. Результуюча квазілінійна динаміка контуру регулювання напруги дає змогу використовувати просту процедуру налаитування регуляторів $і$ забезпечує покращені динамічні характеристики за умови змінної швидкості первинного рушія та потокозчеплення. Результати порівняльного експериментального дослідження зі стандартним алгоритмом непрямого векторного керування також представлено задля порівняння з результатами застосування розробленого алгоритму. На відміну від існуючих рішень, розроблений алгоритм забезпечує стабілізачію показників якості регулювання системи за умови змінних швидкості та потокозчеплення. Експериментально показано, щзо робастний алгоритм керування забезпечує робастне регулювання потокозчеплення і робастну стабілізачію динаміки моментної складової струму, щзо призводить до покращення енергетичної ефективності процесу електромеханічного перетворення. Запропонований регулятор може застосовуватися для систем генерування енергії зі змінною швидкістю. Бібл. 18, рис. 8.

Ключові слова: асинхронний генератор, пряме полеорієнтування, спостерігач потокозчеплення, стабілізація напруги ланки постійного струму, змінна швидкість, генерація енергії.

Надійшла 29.04.2021

Остаточний варіант 31.05.2021 